\title{
CHOICE OF ISLAMIC LAW AS THE GOVERNING LAW IN ISLAMIC FINANCE CONTRACTS: THE UNITED KINGDOM AND NIGERIAN PERSPECTIVES
}

\author{
Kareem Adebayo Olatoye* \\ Abubakri Yekini**
}

\begin{abstract}
The globalisation of Islamic finance has brought the adjudication of Islamic finance disputes before non-Muslim courts and arbitral tribunals in Europe, America and elsewhere. Expectedly, the issue of the validity of selecting Islamic law as the governing law of an Islamic finance contract often arises before these courts and tribunals. The article seeks to address the attitude of the United Kingdom and Nigerian courts to this unique problem. The thesis of the article is that while the parties' reasonable expectations in having their Islamic finance contracts governed by the Shari'ah may be met in Nigeria and by extension in other Muslim-majority countries, the contrary is the case in the United Kingdom and Europe where the courts do not generally favour the application of Islamic law. The article advocates that the doctrine of the proper law of contract should be extended to Islamic finance by upholding Islamic law as the law selected by the parties (on the basis of party autonomy) or alternatively, as the system of law with which an Islamic finance transaction is most closely connected.
\end{abstract}

Keywords: Choice of Islamic law, Islamic finance, Rome I Regulation, party autonomy, proper law of contract

\footnotetext{
Kareem Adebayo Olatoye $(\mathrm{PhD})$ is a Senior Lecturer in the Department of International Law and Islamic Law, Lagos State University, Lagos, Nigeria. Email: kamolatoye@gmail.com.

** Abubakri Yekini is a doctoral student at the Centre for Private International Law, University of Aberdeen, UK and also an Assistant Lecturer, Department of International Law and Islamic Law, Lagos State University, Lagos, Nigeria. Email: a.yekini@abdn.ac.uk. The authors would like to thank the anonymous reviewers for their valuable comments on this article.
} 


\title{
PILIHAN UNDANG-UNDANG ISLAM SEBAGAI UNDANG- UNDANG PENTADBIRAN KONTRAK KEWANGAN ISLAM: PERSPEKTIF UNITED KINGDOM DAN NIGERIA
}

\begin{abstract}
ABSTRAK
Globalisasi kewangan Islam telah membawa adjudikasi pertikaian kewangan Islam di hadapan mahkamah bukan Islam dan tribunal timbang tara di Eropah, Amerika dan di tempat lain. Seperti yang dijangkakan, isu kesahan pemilihan undang-undang Islam sebagai undang-undang mentadbir bagi pertikaian kewangan Islam timbul di hadapan mahkamah-mahkamah dan tribunal tersebut. Makalah ini bertujuan membincangkan sikap mahkamah di United Kingdom dan Nigeria terhadap permasalahan unik ini. Tesis makalah ini ialah: walaupun harapan munasabah pihak-pihak akan dihormati oleh mahkamah di Nigeria dan dipanjangkan juga di negara-negara majoriti Islam yang lain, kes yang sebaliknya berlaku di negara-negara seperti United Kingdom dan Eropah, di mana mahkamah lebih bersandar untuk tidak mengaplikasi undang-undang Islam. Oleh itu, makalah mengusulkan agar doktrin undang-undang yang sepatutnya bagi kontrak dipanjangkan kepada kewangan Islam bagi menegakkan undang-undang Islam sebagai undang-undang yang dipilih oleh pihakpihak (atas dasar autonomi pihak-pihak) atau secara alternatif, sebagai sistem undang-undang yang paling berhubungkait dengan transaksi kewangan Islam.
\end{abstract}

Kata kunci: Pilihan undang-undang Islam, kewangan Islam, Peraturan Rome 1, autonomi pihak-pihak, undangundang kontrak sepatutnya 


\section{INTRODUCTION}

The internationalisation of Islamic finance and, particularly, its operation in non-Muslim countries have given rise to certain emerging issues, one of which is the governing law of an Islamic finance contract. This may not pose a serious challenge in the Muslim-majority countries as the courts therein readily presume and apply Islamic law to disputes arising from Islamic finance. However, the same may not be said of such disputes coming before the courts in Europe and elsewhere where Islamic law is considered to be a foreign law.

This article, therefore, seeks to address the challenge of the selection of Islamic law as the governing law of an Islamic finance contract under the United Kingdom and Nigerian laws. The thesis of the paper is that, while reasonable expectations of parties to an Islamic finance in having their dispute govern by Islamic law may be met in Nigeria and other countries where Islamic law is a forum law, the contrary is the case in the United Kingdom, where the common law has been replaced with continental jurisprudence. The article approaches the discourse from the perspective of private international law. It is argued that the English courts are swayed by extraneous factors in refusing to apply Islamic law to Islamic finance contracts. The paper advocates that the doctrine of the proper law of contract should be extended to Islamic finance by upholding Islamic law as the law selected by the parties (party autonomy) or alternatively, as the system of law with which an Islamic finance is mostly connected.

The second section of the paper discusses the choice of law in contract in the United Kingdom and the attitude of its courts towards the selection of Islamic law. The article discusses various principles on the governing law of a contract under the common law and the Contract (Applicable Law) Act, 1990. The third section discusses the same subject matter under the Nigerian law with a focus on the reception of the common law in Nigeria, its developments by the Nigerian courts and their attitude to Islamic law. The last section concludes the paper by summarising the positions in the United Kingdom and Nigeria and offers some recommendations. 


\section{CHOICE OF ISLAMIC LAW IN THE UNITED KINGDOM}

\section{Express choice of law}

Islamic finance is one of the fastest growing financial markets globally. By its nature, it has a strong connection with Islamic law though not exclusively operated by Muslims. It is available to any interested party like oher conventional financial products. Therefore, both Muslims and non-Muslims alike are participants in this industry.

Usually, parties to Islamic finance contracts do select Islamic law as the governing law of the contract. No rule stipulates that this must be the case, though, that is the practice. It, therefore, means that, in some other instances, it is possible to have an Islamic finance contract where parties, for whatever reason, may fail to stipulate what the governing law of that transaction should be.

Historically, the common law applies the Roman law's concept of pacta sunt servanda which itself, according to Hans Wehberg, ${ }^{1}$ has close links with Islamic teachings among others. ${ }^{2}$ By this doctrine, parties are bound to the contract they freely negotiated. The courts are not to rewrite the contract for the parties but to uphold the same. This is a similitude of the doctrine of freedom of contract, private autonomy or party autonomy. Roman law is said to regard a system of law as peculiar to individuals. Hence, a Roman citizen may claim the protection of its laws irrespective of his location. He may also waive the application of the Roman law in favour of the law of his location. ${ }^{3}$

As at the $18^{\text {th }}$ century, the common law courts had recognised the doctrine of party autonomy and considered it as a key factor in resolving choice of law disputes in contracts. Lord Mansfield laid the foundation in

Hans Wehberg, "Pacta Sunt Servanda," American Journal of International Law, 53(1959): 775.

2 Wehberg cited the Chaldeans and the Chinese as other people who had historical rules evidencing pacta sunt servanda. For the Islamic perspective, he gave his support thus; "For the Islamic peoples, the principle Pacta sunt servanda also has a religious basis: Muslims must abide by their stipulations. This is clearly expressed by the Koran in many places, for example, where it is said: 'Be you true to the obligations which you have undertaken.... Your obligations which you have taken in the sight of Allah. For Allah is your Witness...'."

3 S. M. Richardson, "International Contracts and the Choice of Law," (PhD Thesis, University of Canterbury, 1988), 18. See also J Beale, "What Law Governs the validity of a contract?" Harv. L. R. 23 (1910): 7. 
Robinson $v$ Bland $^{4}$ and other cases that came after it further expounded the doctrine. Consideration for other connecting factors such as lex loci solutionis would only come in where the parties failed to select the governing law of the contract. ${ }^{5}$

The doctrine of party autonomy regarding the choice of governing law of contract was not well developed in England until Professor Dicey propounded the proper law theory in the early part of the $20^{\text {th }}$ century. Prior to that time, various writers like Huber, Dumoulin, Story and Savigny have all acknowledged the freedom of parties to choose the law they wish to govern their contract. However, their concept of autonomy was limited to allowing parties the freedom to choose from either the law of the place of where a contract was made or was to be performed. ${ }^{6}$ Hence, it was not clear from their works whether the choice may include the law of a place not related to the contract.

The idea of absolute party autonomy began in the $20^{\text {th }}$ century when the views of free market economy was rising. It was an era of the desire to 'privatize' private law by making its source independent of the state. ${ }^{7}$ Contracts were seen as private engagements and parties ought to be free to create rights and obligations as they deemed fit. This was the era when Dicey began the proper law of the contract campaign.

According to Dicey, the proper law of contract means 'the law or laws by which the parties intended or may fairly be presumed to have intended the contract to be governed'. ${ }^{8}$ He gives preference to the choice of the parties even if the law chosen has no connection with the contract. The function of the court therefore is mainly to ascertain the parties' choice either as expressly agreed upon or as may be implied from the circumstance of the case. This subjective approach is the hallmark of his postulation. Dicey's approach was opposed by some of his

(1760) 2 Burr 1077.

Gibbs \& Sons v. La Société Industrielle et Commerciale des Métaux (1890) 25 Q.

B. D. 399; Lloyd v. Guibert (1865-66) L.R. 1 Q.B. 115.

6 Peter Edward Nygh, Autonomy in International Contracts, (Oxford: Clarendon Press, 1999) 5.

7 Ralf Michaels, "Non-State Law in the Hague Principles on Choice of Law in International Commercial Contracts," in Varieties of European Economic Law and Regulation: Liber Amicorum for Hans Micklitz, eds. Kai Purnhagen \& Peter Rott, (2014), accessed December 23, 2016, http://scholarship.law.duke.edu/faculty_scholarship/3227.

$8 \quad$ Dicey, Conflict of Laws (London: Sweet \& Maxwell, 5th ed., 1932), Rule 155. 
contemporaries such as Westlake, ${ }^{9}$ Morris and Cheshire. ${ }^{10}$ They accepted the proper law theory but differed with him in the manner of ascertaining the proper law. For instance, Westlake defined the proper law as 'the law of the country with which the contract has the most real connection'. ${ }^{11}$ This presupposes that the proper is the law that has the strongest factual connection with the contract.

The English courts have been influenced by Dicey's proper law theory and they have continuously applied it till date. Vita Food Products Inc. v. Unus Shipping $\mathrm{Co}^{12}$ is a landmark decision that exemplifies the supremacy of parties' choice of governing law. In this case, the appellant contracted with the respondent for the shipment of herrings from Newfoundland to New York on a Canadian vessel, The Hurry On under a bill of lading issued in Newfoundland in 1935. The vessel was negligently grounded at Nova Scotia. The herrings were received by the appellants in New York in damaged condition. The owner was sued in Nova Scotia. The bill of lading which contained a choice of English law as governing law exempted the carrier from liability in the case of negligence. Meanwhile, the Newfoundland Carriage of Goods by Sea Act, 1932 incorporates the 1932 Hague Rules, and by its s.3, it is provided that every bill of lading must contain a paramount clause incorporating the Hague Rules. The bill of lading in question omitted the paramount clause.

The Appellant argued that English law had no connection with the subject matter and should not be applied. Rather, the law of Newfoundland or New York applied to the transaction. The Respondent raised the defence of exemption of liability as allowed by English law. The appellant objected and claimed that the bill of lading was illegal, having failed to include the paramount clause. In the alternative, the appellant argued for the application of the Harter Act (US law) which was incorporated into the bill of lading. The Nova Scotia Supreme Court rejected the contention of the Appellant and held that if the bill was illegal, then the action must fail as both parties were in pari delicto. On further appeal, the Privy Council decided that provisions of the

9 Westlake, Private International Law (London: Sweet \& Maxwell, 7th ed., 1925), s. 212.

10 Morris and Cheshire, "The Proper Law of a Contract in the Conflict of Laws," $L$. Q. Rev. 56 (1940): 320.

11 Westlake.

12 Vita Food Products Inc. v. Unus Shipping Co (1939) A.C. 277. 
Newfoundland were directory and not mandatory. Hence, the contract could not be nullified by its non-compliance. Lord Wright concluded that the express intention of the parties is the litmus test to determine proper law of a contract. However, he also noted that such a clear choice might not be conclusive. His Lordship, therefore, set some exceptions to the rule. The exceptions are that the law selected by parties should be 'bona fide, and legal and provided there be no reason for avoiding the choice on the grounds of public policy., 13

Contrary to the restrictive attitude maintained in jurisdictions such as the United States, ${ }^{14}$ the English courts continued to give preference to the law chosen by the parties as the proper law of the contract. The three exceptions introduced by Lord Wright are construed strictly and narrowly. As David Pierce points out, there is no English authority where the court has rejected an express choice of law. ${ }^{15}$ As decided in Vita Food Products Inc case,${ }^{16}$ the absence of any connection between the case/parties and England was irrelevant. Also the mere fact that the contract might be illegal under foreign law would not necessarily make it unenforceable in England provided it is valid under English law.

While the public policy exception is clear, the 'bona fide and legal' exception may need some clarification. Bona fide has been described as an exercise done in good faith, honestly and without fraud ${ }^{17}$ or an act done with a genuine motive. ${ }^{18}$ In this context, parties' choice of a foreign law must not have arisen from a bad motive, for instance, in an attempt to evade an otherwise applicable forum law. This implies that where parties deliberately contract to evade certain obligations under the forum law or

See Richard J. Bauerfeld, "Effectiveness of Choice-of-Law Clauses in Contract Conflicts of Law: Party Autonomy or Objective Determination?," Colum. L. Rev. 82 (1982): 1672; Symeon Symeonides, "Party Autonomy in International Contracts and the Multiple Ways of Slicing the Apple," Brook. J. Int'lL. 39 (2014): 1129. Many Latin American States also reject the doctrine. See María Mercedes Albornoz, 'Choice of Law in International Contracts in Latin American Legal Systems' Journal of Private International Law, 6 (2010): 31.

15 David G. Pierce, "Post-Formation Choice of Law in Contract," Mod. L. Rev. 50 (1987): 179.

16 (1939) A.C. 277.

17 Jowitt's Dictionary of English Law, Daniel Greenberg ed. (London: Sweet \& Maxwell, $4^{\text {th }}$. ed., 2015).

18 United Dominions Trust Ltd v Kirkwood [1966] 1 Q.B. 783. 
an otherwise applicable law by choosing the law of another state, the English court may disregard such an express choice.

Selecting a law that has no connection with the contract does not presume illegality or mala fide. The appropriate considerations the courts are expected to examine are whether the motive seek to legalize an otherwise illegal transaction or evade some other mandatory rules of the forum law. Where such an intention could not be found, then the court shall regard and apply the chosen law. An example of such mala fide is seen in Golden Acres Limited v. Queensland Estates Pty. Ltd,${ }^{19}$ a popular Australian case where the court rejected a choice of Hong Kong law when it was realized that the parties in a settlement contract opted for Hong Kong law to evade the provisions of the Australian Auctioneers, Real Estate Agents, Debt Collectors and Motor Dealers Act.

Some attempts have been made to disregard the freedom of parties to a contract to choose the governing law. Lord Denning echoed this position in Boissevain v. Weil, ${ }^{20}$ when he held that 'notwithstanding what was said in Vita Food Products v. Unus Shipping Co., I do not believe that parties are free to stipulate by what law the validity of their contract is to be determined. Their intention is only one of the factors to be taken into account ${ }^{21}$ Lord Denning relied on the objective test of Westlake by concluding that intention of the parties is merely one of the factors to be considered and may be displaced if other stronger connections suggest another system of law.

Lord Denning's approach to restrict party autonomy was rejected by subsequent House of Lords decisions. In Bonython v. Commonwealth of Australia, ${ }^{22}$ Lord Simonds defines proper law of contract as the system of law by reference to which the contract was made or that with which the transaction has its closest and most real connection'. Lord Simonds went on to clarify that the proper law was the law selected by the parties and the second leg of his definition- 'that with which the transaction has its closest and most real connection' would arise where no law was selected by parties. ${ }^{23}$ Also, in Amin Rasheed Shipping Corporation $v$ Kuwaiti Insurance, ${ }^{24}$ the House of Lords once again reaffirmed party

(1969) QR 378.

(1949) 1 K.B. 482.

Ibid., 491.

(1951) A.C. 201.

Ibid., 221.

(1984) AC 50. 
autonomy. It reassessed previous decisions on the doctrine of proper law of contract and concluded that it is the system of law selected by the parties and where no selection is made, the law with which the contract is mostly connected applies.

\section{The Contracts (Applicable Law) Act 1990}

The United Kingdom joined the European Economic Community (now the European Union) in 1973. As a member of the Union, the English courts are bound to apply the EU laws and regulations. Their decisions are also subject to decision of the European Court of Justice. ${ }^{25}$ In 1990 , the United Kingdom enacted the Contracts (Applicable Law) Act $1990{ }^{26}$ This legislation domesticated the Rome Convention on the Law Applicable to Contractual Obligations, 1980. The Rome Convention on the other hand has been replaced with the Council Regulation (EC) No $593 / 2008$ (Rome I Regulation) ${ }^{27}$ on the law applicable to contractual obligations.

Article 3 of the Regulation reiterates the supremacy of party autonomy by stipulating that: 'a contract shall be governed by the law chosen by the parties'. This is a restatement of the doctrine of the proper law of contract under common law. Where a choice is not expressed, the system of law that is most connected with the contract applies. However, it further provides that the parties' choice shall not prejudice the application of mandatory provisions of foreign law, particularly when the foreign country has a strong connection with the contract. ${ }^{28}$ This is the general rule from the Regulation.

The Regulation describes mandatory provisions as laws which a State enacts with the aim of 'safeguarding its public interests, such as its

See section 3 of the Contracts (Applicable Law) Act 1990 which provides that "Any question as to the meaning or effect of any provision of the Conventions shall, if not referred to the European Court in accordance with the Brussels Protocol, be determined in accordance with the principles laid down by, and any relevant decision of, the European Court."

26 The Act came into force on $1^{\text {st }}$ April 1991 under the Contracts (Applicable Law) Act 1990 (Commencement No 1) Order, 1991.

27 Regulation (EC) NO 593/2008 of the European Parliament and of the Council of 17 June 2008 on the law applicable to contractual obligations (Rome I), L 177/6 Official Journal of the European Union 4.7.2008. 
political, social or economic organisation, to such an extent that they apply to any situation falling within their scope'. ${ }^{29}$ Like the Canadian position, the Regulation requires that before such mandatory provisions can displace the parties' choice, the courts should critically consider 'their nature and purpose and to the consequences of their application or non-application' in respect of the contract in questions. ${ }^{30}$

In the absence of specific choice, a contract is govern by the law with which it is mostly connected. ${ }^{31}$ For a contract of sale, for instance, the law of the habitual residence of the seller applies ${ }^{32}$ while for a contract of service, the law of the habitual residence of the service provider is the proper law. ${ }^{33}$ Where a contract does not fit into the above two examples, the law of the habitual residence of the party, who is to effect the characteristic performance ${ }^{34}$ applies. ${ }^{35}$ The Regulation has provisions for other special contracts such as consumer contracts, insurance contracts, employment contracts and others where the law seeks to protect the weaker parties by providing for the law of the habitual residence of that weaker party, i.e consumer, employee, etc.

By March 2019, the United Kingdom shall cease to be a member of the European Union having triggered Article 50 of the Treaty of Lisbon that gives any EU member the right to withdraw unilaterally from the

29 Ibid., Art. 9 (1).

30 Ibid., Art 9(3). In Banco Santander Totta SA v Companhia de Carris de Ferro de Lisboa SA[2016] EWCA Civ 1267, the English court refused to set aside an express choice of English law in a contract between Portuguese state-owned transport companies and a Portuguese Bank because art. 437 of the Portuguese Civil Code which the Plaintiff seeks to invoke as a mandatory rule contained a waiver clause and as such the court concluded that parties may derogate from the provisions of the Code which would have otherwise made Portuguese law the proper law.

31 Lawlor v Sandvik Mining and Construction Mobile Crushers and Screens Ltd (2012) 2 Lloyd's Rep. 25; Cox v Ergo Versicherung AG (formerly Victoria) (2012) EWCA Civ 1001.

32 Rome I Regulation, Art 4(1) (a).

33 Ibid., Art 4(1) (b).

34 For the understanding of the meaning of 'characteristic performance', see Kurt Lipstein, "Characteristic Performance, A New Concept in the Conflict of Laws in Matters of Contract for the EEC," Nw. J. Int'l L. \& Bus. 3 (1981): 402.

35 Rome I Regulation, Art 4 (2). 
Union. ${ }^{36}$ There is no radical difference between the Contracts (Applicable Law) Act and the common law in this respect. The doctrine of the proper law of contract which promotes party autonomy remains the general rule under the Act. This suggests that Brexit may not have any significant effect on the proper law of the contract. It is doubtful whether the Act will be repealed.

One key issue that must, however, be borne in mind is that the Contracts (Applicable Law) Act will be interpreted after Brexit in accordance with English precepts. ${ }^{37}$ Section 3 of the Act which requires the English courts to interpret the Act in line with the decisions of the European court will cease to have effect. In this regard, two areas that may witness changes are the provisions on mandatory rules and the emphasis on selection of the law of a State law. The common law does not lay much emphasis on these two areas unlike the Rome I Regulation. The English courts may therefore be very flexible when dealing with these two issues after Brexit.

\section{Treatment of Islamic law before the English Courts}

From the perspective of English law, Islamic law is a foreign law. It is considered as a fact which must be pleaded and proved before the court can apply it. Where this is not done, the general principle of English law is that the English court will assume that the content of that foreign law is the same as English law and English law therefore applies. ${ }^{38}$ Since the court is not learned in Islamic law, it is required that the contents of Islamic law should be proved by persons who are experts in the field. ${ }^{39}$ In the area of family law, the English courts apply Islamic law fairly, and there are a number of cases that substantiate this point. ${ }^{40}$ However, in the

Accessed December 24, 2016, http://www.lisbon-treaty.org/wcm/the-lisbontreaty/treaty-on-European- union-and-comments/title-6-final-provisions/137article-50.html.

Catharine MacMillan, “The Impact of Brexit upon English Contract Law,” King's Law Journal, 27 (2016): 428.

38 Ascherberg, Hopwood \& Crew v Casa Musicale Sonzogno (1971) 1 All EE 577; King of Spain v. Machado (1827) 4 Russ. 225.

39 Lozard Bros. \& Co. v. Midland Bank, [1933] A.C. 289; Dicey, Morris \& Collins, The Conflict of Laws (14th edition, Sweet \& Maxwell, London 2006) 261-262. 
field of contract law, the matter is not as straightforward as it is in family law. Some cases will be discussed to assess the attitude of the English courts to the application of Islamic law to Islamic finances and contracts.

The first to be considered is Abdel Hadi Abdallah Al Qahtani \& Sons Beverage Industry Company $v$ Andrew Antliff. ${ }^{41}$ In this case, the court was called upon to determine a number of disputes arising from the defendant's conduct in the course of employment with the plaintiff. Specifically, the court was to identify when the contract took effect between the parties, issues of bribery, theft and breach of trust in connection with the employment. The defendant is a British citizen who worked for the Plaintiff in Saudi Arabia. The court agreed that Islamic law was applicable being the law applied in Saudi Arabia. Dr Mujahid M Al-Sawwaf and Ian Edge were called as experts to give an opinion on the position of the Shariah in respect of the issues before the court. It was difficult for the court to separate the Shariah from the Saudi legal system. Unlike what is obtainable in other Muslim countries, Saudi has no separate code or laws for civil procedure for commercial law. However, the court found that Saudi Arabia has a form of codification of Shariah rules as applied in Saudi Arabia in the Majallah which runs into several volumes. The court, however, did not base its decision on the Majallah but purely on the provisions of the Shariah as distilled from several Islamic texts by the experts.

Apart from Abdel Hadi Abdallah Al Qahtani \& Sons Beverage Industry Company's case, other cases that came before it suggested that the English courts lean against the application of Islamic law even where it is expressly agreed by the parties to a contract. In Musawi $v$ RE International (UK) Ltd, the claimant sought to enforce a right obtained under an arbitral award against the defendants in respect of some acres of land adjoining the Wembley Stadium, which was subject to acquisition by the London Development Agency. The Claimant and the other defendants were members of the Shia community and had jointly invested in the said land. Their agreement was to be governed by the Shia Shariah law. The court rejected the application of Islamic law as it was not the law of a country as required by the common law. In the court's

\footnotetext{
Civ 17 applying Islamic law of Talaq (iddah); Al Midani and Another v Al Midani and Others (1999) 1 Lloyd's Rep 923 (recognizing Islamic law of succession as a proper law). (2010) EWHC 1735 (Comm).
} 
view, with the enactment of the Contract (Applicable Law) 1990, parties could only choose the law of a country and not a non-state law. ${ }^{42}$ The court was also not persuaded that s.46 (1) (b) of the Arbitration Act 1996 allows parties to choose a law other than the law of a state.

Shamil Bank of Bahrain EC v Beximco Pharmaceuticals Ltd and Others ${ }^{43}$ is a case that falls squarely under Islamic finance. The plaintiff entered into a murabahah agreement with the first and second defendants, and the third to fifth defendants acted as guarantors. The Bahraini bank was well known as an Islamic bank and operates on the principles of the Shari'ah. The governing law of the contract stated that "Subject to the principles of the Glorious Shari'a, this agreement shall be governed by and construed in accordance with the laws of England.' The bank obtained a summary judgment against the defendants when they could not repay the outstanding sum from the transaction. The defendant appealed on the ground that the contract was unenforceable as it was contrary to the Shari' ah. It claimed the transaction was a disguised loan agreement with interest. It occurred that Beximco Pharmaceuticals Ltd did not apply the sum advanced for the purchase of any goods or equipment but rather used it as part of working capital. Experts were called to ascertain the position of the Shariah on the transaction.

Morrison J clearly ruled out the application of the Shari'ah by holding thus:

First, article 3(1) of the Rome Convention on the Law Applicable to Contractual Obligations (which by section 2(1) of the Contracts (Applicable Law) Act 1990 has the force of law in the United Kingdom) contemplates that a contract "shall be governed by the law chosen by the parties" and article 1(1) of the Rome Convention makes it clear that the reference to the parties' choice of the law to govern a contract is a reference to the law of a country. There is no provision for the choice or application of a non-national system of law such as Sharia law... In any event, the principles of the Sharia are not simply principles of law but principles which apply to other aspects of life and behaviour. Even treating the principles of Sharia as principles of law, the application of such principles in relation to matters of commerce and banking were plainly matters of controversy. In particular, there is controversy as to the strictness with which principles of Sharia law will 
be interpreted or applied. In consequence, it was highly improbable that the parties to the agreements intended an English court to determine any dispute as to the nature or application of such controversial religious principles which would involve it in the task of deciding between opposing points of view which themselves might be based on geopolitical and particular religious beliefs.

The Court of Appeal agreed with the above reasoning of the lower court and affirmed the decision. ${ }^{44}$ It must first be acknowledged that the parties in this transaction brought about the controversy surrounding the choice of law by wording it in such a way as to make both Islamic law and English law applicable. The wording gave rise to the problem of interpretation as to whether they intended the two laws to apply or whether Islamic law should supersede English law where there is conflict or, as the court held, whether the reference to Islamic law was only intended to showcase the nature of the transactions carried out by the bank. ${ }^{45}$

Other reasons stated by the court for applying English law show that even if parties had only specified Islamic law as the governing law, the court would still not apply it because, in the interpretation of the court, the Contract (Applicable Law) Act, which incorporated the Rome Convention, only contemplated the law of a country. Admittedly, there is an ongoing debate as to whether non-state laws should be allowed to govern contracts, there is no serious justification from the body of precedents or even the Act to show that non-state laws are expressly excluded, assuming, but not conceding, that Islamic law is a non-state law.

Article 1 of the Convention provides that 'the rules of this Convention shall apply to contractual obligations in any situation

44 The aspect of the decision refusing Islamic law on the basis of uncertainty in its principles has been criticized by some authors as being over exaggerated. See Nicholas H. D. Foster, "Islamic Finance Law as an Emergent Legal System," Arab Law Quarterly, 21 (2) (2007): 185.

45 A closer scenario could also be seen in Islamic Investment Company of the Gulf (Bahamas) Ltd. v Symphony Gems N.V. \& Ors. (2002) WL 346969 where the preamble of a murabaha agreement states that "the Purchaser wishes to deal with the Seller for the purpose of purchasing Supplies (as hereinafter defined) under this Agreement in accordance with the Islamic Shariah" and yet Clause 25 of the same agreement chose English law as the governing law of the transaction. 
involving a choice between the laws of different countries'. Where the dispute is between the choice of a state and non-state law, it is submitted that the Convention does not cover such a situation. The solution should lie outside the Convention. One would have expected the court to turn to the common law for guidance. Unfortunately, the same interpretation has been extended to the common law principles even though it is doubtful if the position has ever been part of the common law. ${ }^{46}$ It is unsurprising that, the court in Musawi v RE International (UK) Ltd refused to apply Islamic law despite the fact that the agreement in question predated the Contract (Applicable Law) Act, 1990.

It is also argued here that the treatment of Islamic law as non-state law is inappropriate. To the extent that it is not codified and styled 'the laws of State X', may make the argument that it is a non-state law attractive. Islamic law is, however, more than that. It is a system of law which, though rooted in the Quran and hadith, is applied in many Muslim-majority states and it is an integral part of their legal systems. ${ }^{47}$ In Abdel Hadi Abdallah Al Qahtani \& Sons Beverage Industry Company $v$ Andrew Antliff, the court found it hard to separate the Saudi legal system from the Shariah law for instance and, eventually, it was applied.

Many of the dicta on choice of law in contract under the common law refers to 'system of law' and not necessarily the law of a country. For instance Per Lord Reid deciding the proper law in Compagnie d'Armement Maritime S.A. Appellants $v$ Compagnie Tunisienne de Navigation S.A. [1971] A.C. 572 decided that 'the proper law of the contract is that of the place or system with which it is most closely associated'. Lord Diplock in the same case decided that 'the proper law is the system of law with which the contract has its closest association, viz., French law'. Salmon LJ in Tzortzis and Another v Monark Line A/B [1968] 1 W.L.R. 406 also holds that 'what is the system of law with which the transaction has its closest and most real connection? ... there can be no question but that the system of law to be applied would be Swedish law; that clearly is the system with which the transaction has its closest and most real connection and all the other factors which usually point to one system of law or another, here point to the Swedish system of law'. While not ruling out that a system of law will ordinarily refers to the law of a country, it does not exclude the application of other law that have such degree of systematization and certainty. Hence, the emphasis is on 'system' rather than country. Therefore, if Islamic law qualifies as a system of law, which in our opinion it does, there is nothing justifying the exclusion of its application. Halpern $v$ Halpern (supra) and other cases expressly deciding that non-state laws are not applicable in contracts are post-1990 cases which must have been influenced by the European regime. 
It is a complete system of law with clearly defined hierarchical sources, and well developed legal principles and maxims which deal with every factual and legal issue. It cannot be placed in the same category with purely non-state laws such as lex mercatoria or UNIDROIT Principles of International Commercial Contracts which are not really a system of law on their own.

Rather, Islamic law is likened to the common law of England which was nurtured in England and now applies with variations depending on the location. The common law is not codified, yet it is accepted as English law. It is doubtful if any court would set aside a choice of law styled 'common law' and regard it as non-state law. Even if it is not stated as 'common law of England', the court concerned will naturally presume it as such, despite the fact that there is no universal 'common law' in the world ${ }^{48}$. Many provisions of the common law as applied in Canada, Australia and the United States are different from how they are applied in England. Several factors considered by the court, such as the application of Shariah law to other aspects of life and behaviours, inherent controversies and the fact that it is a religious law, are extraneous factors which neither have any theoretical basis nor legal justification. Alternatively, were the court to refer the matter to the law of the place of the characteristic performer as required by article 4 of the Convention, the court would have found Bahraini law applicable. If the court had directed itself to ask whether the Islamic law is part of Bahraini law, invariably, the answer would have been in the affirmative, and that would mean Islamic law ought to have been applied. ${ }^{49}$

The court ought to respect the parties' selection of Islamic law and apply it as the proper law of the contract. Apart from this, it is also the system of law with which the contract is connected. Murabahah, musharakah, sukuk and others are exclusively Islamic finance contracts. The parties have legitimate expectations in opting for an Islamic finance and selecting Islamic law as governing law. No system of law could be

48 John David McClean, 'A Common Inheritance? An Examination of the Private International Law Tradition of the Commonwealth,' Recueil des Cours, (The Hague: Martinus Nijhoff Publishers, 1996) 260.

49 It does appear that the Western courts and arbitral tribunals generally have wrong perception about the adequacy of Islamic law in addressing contracts. Hence, the arbitrators in Ruler of Qatar v. International Marine Oil Co. Ltd. jettisoned Islamic law in favour of English law despite noting that the former was applicable. See Ruler of Qatar v. International Marine Oil Co. Ltd., 20 I.L.R. 534 (1953). 
better connected to it than Islamic law. The court ought to help the parties to realize their expectations by giving effect to their selected governing law.

The last point to note here is that the English court allows the incorporation of specific principles of Shari'ah as part of the contractual terms. Hence, the court may construe such terms as reduced into writing by the parties like any other term of the contract. ${ }^{50}$ It is contended that the requirement of incorporation of specific principles of Shari'ah into an Islamic finance contract is a heavy burden placed on parties. The courts should ordinarily uphold the selection of Islamic law once there is any reference to it. Parties cannot be expected to reduce all the detailed principles and provisions of Islamic law in a contractual document. It is simply unrealistic and impracticable.$^{51}$ Insisting on full incorporation is a demonstration of an unwillingness to recognise the application of Islamic law.

\section{CHOICE OF ISLAMIC LAW IN NIGERIA}

Nigeria inherited the common law legacy from the United Kingdom and it has influenced her legal development. The common law of England, the doctrine of equity and statutes of general application in force as at $1 \mathrm{st}$ January 1900, all have direct force of law in Nigeria. ${ }^{52}$ Post-1900 English decisions are no longer binding on Nigerian courts, but they have persuasive effects. ${ }^{53}$ The choice of governing law for contracts under Nigerian law has its root in the common law. Presently, there is no Nigerian statute in force that regulates the choice of governing law of a contract. Hence, reliance shall be made on decisions of the courts.

Other authors have also criticized this aspect of English law's position on the Shari'ah. See Julio C. Colon, "Choice of Law and Islamic Finance," Texas International Law Journal, 16 (2011): 411-435; Anowar Zahid and Hasani Mohd Ali, "Shari' ah as a Choice of Law in International Islamic Financial Contracts: Shamil Bank of Bahrain Case Revisited," US-China Law Review, 10 (2013): 27. S.32, Interpretation Act, 2004. 
Having analysed the common law position earlier in this paper, the same shall not be repeated here. Nigerian courts, like their English counterparts, highly revere the concept of party autonomy. In numerous cases, the courts have stated emphatically that the duty of the courts is to enforce the terms of the contract and not to rewrite it for parties. In Nika Fishing Co. Ltd. v. Lavina Corporation, ${ }^{54}$ Niki Tobi JSC clearly set out the principle in the following words:

Where there is a contract regulating any arrangement between the parties, the main duty of the court is to interpret that contract and to give effect to the wishes of the parties as expressed in the contract document...It is the law that parties to an agreement retain the commercial freedom to determine their own terms. No other person, not even the court, can determine the terms of contract between parties thereto. The duty of the court is to strictly interpret the terms of the agreement on its clear wordings. .. Finally, it is not the function of a court of law either to make agreements for the parties or to change their agreements as made.

Unlike England, which has London as a major hub for the settlement of international disputes, very few cases have been reported concerning the choice of law in contract in Nigeria. The locus classicus under Nigerian law is the Supreme Court decision in Sonnar (Nig.) Ltd \& Anor. v. Partenreedri M. S. Nordwind Owners of the Ship M. V. Nordwind \& Anor. ${ }^{55}$ The plaintiffs sued the defendants before the Lagos High Court for non-delivery of 25,322 bags of parboiled long grain rice, which were shipped from Thailand to Lagos aboard the defendants' vessel. The ship owners were based in Germany, the shipping company was based in Liberia and the $3^{\text {rd }}$ defendant, the supplier, was based in Thailand. The relevant clause of the bill of lading stipulates that "any dispute arising under this Bill of Lading shall be decided in the country where the "carrier" has his principal place of business and the law of such country shall apply except as provided elsewhere herein". In essence, German law was the choice of governing law for the contract.

The main issue before the lower court was whether the court should grant a stay of proceedings out of respect for parties' choice of German jurisdiction. The lower court noted that German law could not be ignored 
if the case were to be tried in Nigeria and for other reasons, he granted a stay of proceedings in favour of German courts. This point was argued at the Supreme Court. The Supreme Court disagreed with the lower courts, and in making its pronouncements, the Court touched on the choice of governing law for that contract, per obiter as follows:

What is the relevance of German law to a Liberian ship owner and a Nigerian Shipper? I see none. It is also conceded that when the intentions of the parties to a contract as to the law governing the contract are expressed in words, this expressed intention is general and as a general rule determines the law of the contract. But to be effective, the choice of law must be real, genuine, bonafide, legal, and reasonable. It should not be capricious and absurd. Choosing German law to govern a contract between a Nigerian shipper and a Liberian ship owner is to my mind capricious and unreasonable. Luckily, nowadays a clause of the proper law by the parties is not considered by the court as conclusive.

Justice Oputa's position, quoted above, summarised the approach of Nigerian courts to the choice of governing law of contract. It confirms the dictum of Lord Wright as expounded in Vita Food's Production, though not citing the case. However, the Supreme Court's exceptions are beyond the scope of Lord Wright's bona fide and public policy. The Court added that such clause must be real, genuine and reasonable. While 'genuine' has a semblance with 'bona fide', 'real' and 'reasonable' mean different things entirely. Though Justice Oputa did not define what he meant by 'real' and 'reasonable', his understanding of these words can be seen from their application in the case.

The Court refused to honour the choice of German law because it had no connection with the contract. The court relied on three Australian cases of Golden Acres Ltd. v. Queensland Estates Ltd, ${ }^{56}$ Queensland Estate Ltd. v. Collas ${ }^{57}$ and Freehold Land Investment Ltd. v. Queensland Estate Ltd. $(1970)^{58}$ to arrive at the conclusion that a chosen law must have a connection with the contract. This informs the question asked by the court: 'What is the relevance of German law to a Liberian ship owner and a Nigerian Shipper? I see none'. In the jurisprudence of the Nigerian

(1969) St. R. Qd 378.

(1971) St. R. Qd 75.

(1970) 123 C.L.R. 418. 
Supreme Court, a choice must not only be bona fide and not contrary to public policy but it must also be connected with the transaction, otherwise the court will be at liberty to apply it or reject it. It must be mentioned that the Supreme Court wrongly conceived the position of the Australian cases it relied on. The cases are not authority for the fact that a chosen law must be connected with the contract. That is not what the cases decided. As discussed earlier in this paper, the Australian court indeed admitted in Golden Acres Ltd. v. Queensland Estates Ltd that the parties had validly chosen Hong Kong law but refused to honour that choice simply because the parties were attempting to evade the Australian Auctioneers, Real Estate Agents, Debt Collectors and Motor Dealers Act. The status of Islamic law in Nigeria is different from that of the United Kingdom. It is part and parcel of Nigerian law and has a direct force of law. Islamic law is not a foreign law in Nigeria and may not need to be proved, except in some parts of Nigeria where there are no Shariah courts as a court of first instance. In these states, parties that seek to have Shariah law applied in their action may need to establish it before the courts, as the judges are not learned in Islamic law ${ }^{59}$. The case is different at the Court of Appeal and Supreme Court. In these appellate courts, the Constitution requires a certain minimum number of justices learned in Islamic law to be members of these courts. ${ }^{60}$

Therefore, where parties subject their contract to Islamic law, and especially in cases of Islamic finance, the Nigerian courts will be prepared to uphold parties' choice by applying Islamic law as the governing law. Islamic law creates and defines various Islamic finance contracts. The courts may readily presume Islamic law to be the governing law of such contracts except where the contrary is expressed or intended by the parties. The relevant factor is the contract itself and not the parties to the contract. The point was buttressed by Salami PCA (as he then was) when he observed in Maidara $v$ Halilu $^{61}$ as follows:

But Islamic Law of Contract including Sharikat al-mudharaba and muravalat (sic) is not applicable to a contract merely because the parties are Muslims. The appellant, in the circumstance, had a burden

59 See sections 16, 17 and 69 of the Evidence Act 2011. This is the position of the law with respect of customary law which some courts have assumed to be a variant of Islamic law in Nigeria.

60 S.288 (1) of the 1999 Constitution of the Federal Republic of Nigeria.

61 (2000) LPELR-10695(CA). 
of proof that there was cooperation or partnership agreement between the parties to pull their resources together. There must be evidence that respondent agreed to supply the capital and the appellant agreed to contribute his expertise as well as sharing of the profit (if any) before the principle of Sharikat al-mudharaba could be invoked.

The above dictum underscores that Nigerian courts have no difficulty in upholding choice of Islamic law in Islamic finance contracts provided the contract has the elements of Islamic finance and parties intended the law to apply.

Islamic finance is just beginning to evolve in Nigeria, and there is no doubt that more specific judicial decisions will begin to emerge. As such the exact scope and extent of the application of principles of Islamic finance law in Nigeria, especially in parts of the country where Shariah courts are non-existent, shall become evident.

Nigerian courts may not be persuaded by the decision of the English courts in Shamil because the decision was reached by construing the Rome I Regulation and not common law principles. In any case, the status of Islamic law is quite different in the United Kingdom and Nigeria based on the considerations that have been stated above.

\section{CONCLUDING REMARKS}

There appears to be a constant struggle in synchronizing the orthodox principles of Islamic law in coming up with Islamic financial options to suit modern finance. Although, many Islamic banks and financial institutions have a Shariah Advisory Board which is tasked with the responsibility of ensuring that Islamic finance products are Shariah compliant, ensuring that the contracts are indeed executed or performed as per the Shariah Board certification remains an issue.

In the area of choice of law, one ordinarily expects that Islamic financial contracts should be expressly or presumably subject to Islamic law. This raises a conflict of law issues particularly when such contracts are between parties in different countries, or the disputes are litigated in non-Islamic courts. This potentially causes other laws compete with Islamic law as the governing law because the transaction has a connection with other states which may not necessarily apply Islamic law. 
The paper has considered this question in the light of English and Nigerian laws. The English law has evolved from the common law principles to Rome I Regulation. The latter now applies to conflict of law issues arising from contractual relations before the English courts. It is opined that Brexit may not have any significant effect on contractual choice of governing law because the Contracts (Applicable) Act which domesticates the Rome I regulation is closer to the common law regime. Islamic law has not enjoyed a favourable reception in the English courts basically for two basic reasons. First, by common law, the English court has the tendency of applying English law to every dispute arising from contracts if the matter has a minimal connection with England, provided there is no express agreement to the contrary. This connection ranges from choosing England as the seat of arbitration to using some popular English standard forms as the basis of the contractual terms.

The paper criticises the unfavourable treatment of Islamic law as the choice of law under the Rome I Regulation and argues that, assuming Islamic law is a non-state law, then it does not fall within the scope of Rome I Regulation. The rejection of Islamic law as a choice of law violates the doctrine of party autonomy which is the hallmark of both the common law and the Regulation. It disregards the expectation of parties to an Islamic finance contract who desired that Islamic law should govern their contract. The rejection of Islamic law is a threat to the sustainability of this alternative finance which is now worth approximately 2.6 trillion dollars globally, with its recognition and acceptance by many governments in various continents.

Unlike the United Kingdom, the situation appears to be different in Nigeria where Islamic law has a very high likelihood of favourable response and application from the courts. Some authorities suggest that Islamic law may be a valid choice of law provided the parties make an express intention to be so bound be the law and the contract has a connection with Islamic law. In the absence of an explicit choice, the court may still find Islamic law as the governing law of a contract of Islamic finance since such contracts are creation of Islamic law and parties are presumed to have their contract governed by it except when such presumption is negated by other factors.

Islamic finance companies need to consider this emerging trend in the rejection of Islamic law as governing law when drafting the choice of court and applicable law clauses. The practice of subjecting Islamic finance to both Islamic law and English law should be discouraged, as the English courts will prefer to apply English law rather than Islamic 
law. It is advisable to select only Islamic law as the governing law. Even if the court refused to recognise Islamic law as a state law, the Rome Convention stipulates that the law of the state of the characteristic performer applies. In many cases, this will be the law of the state where the Islamic bank is resident. This situation may however be counterproductive where the Islamic bank is resident in a non-Muslim country.

As some other authors have suggested, ${ }^{62}$ another way out is for parties to select Islamic law as applied in a particular country as the governing law. This implies that the law of that named country is the applicable law and it may be useful in meeting the reasonable expectations of the parties especially if the matter is coming up before a European court (including the English courts) where 'law' is interpreted as the law of a state. In the alternative, parties may incorporate certain specific principles of Islamic finance such as riba and garar as part of the terms of the contract. It enables the court to interpret the whole contract including that aspect of riba and garar that have been included in the contract. The non-Islamic courts may then be forced to adopt these principles as stipulated in the Shariah to resolve any controversy arising from the contract. 